\title{
Review on Heterosis and Combining Ability Study for Yield and Morphological Characters of Coffee (Coffea arabica L) in Ethiopia
}

\author{
Dula Geneti \\ Ethiopian Institute of Agricultural Research, Jimma Agricultural Research Center, P.O. Box 192, Jimma, \\ Ethiopia
}

\begin{abstract}
Ethiopia is both the center of origin and diversification of Coffee arabica. Despite the existence of high genetic diversity in coffee population that provides immense opportunities for improvement program, shortage of improved varieties (pure line and hybrid varieties) is the major one. It is obvious that research work carried out so far on coffee genetics and breeding was not adequate to address these diverse agro-ecologies of the country. Heterosis and combining ability studies are some of the basic breeding tools to address such problems. Some studies had been focused on assessment of heterosis and combining ability analysis for yield and morphological characters of coffee in Ethiopia and the presence of heterosis was reported in crosses of selected indigenous C. arabica L. varieties in Ethiopia under different set of studies mainly due to presence of diverse parental lines. These results clearly suggested that the possibility to bring significant coffee improvement through heterosis and combining ability analysis. Therefore, continuous crossing program should be required to acquire many more cross combinations for intensive and extensive evaluation to develop better performing and high yielding hybrids for Ethiopian origin coffee.
\end{abstract}

Keywords: Coffee Arabica, morphological traits, yield, Heterosis and combining ability

DOI: $10.7176 /$ JEES/9-12-03

Publication date: December $31^{\text {st }} 2019$

\section{Introduction}

Coffee (Coffea arabica L.) belongs to the family Rubiaceae and the genus Coffea (Coste, 1992). The two important commercial species among 124 species in the genus Coffea (Davis et al., 2012) are Arabica coffee and Robusta coffee (Coffea canephora P.), in which the former is the only tetraploid species $(2 \mathrm{n}=4 \mathrm{x}=44)$, while the latter is diploid $(2 \mathrm{n}=2 \mathrm{x}=22)$ (Gichuru et al., 2008) both cover about 10 million hectares worldwide (Bunn, 2015). Coffee arabica, unlike many other coffee types is considered to be a $95 \%$ self-fertile and only $5 \%$ cross fertile species, meaning it can set fruit from its own pollen (Veddeler et al., 2008). In Ethiopia, the total land area coverage of Arabica coffee is estimated to be 700,474.69 ha with an annual average production of 469,091.1 tonnes, out of which over a half is consumed locally (CSA, 2016/2017).

Ethiopia is both the center of origin and diversification of C. arabica L. (Bayetta, 2001). The crop spreads widely in the country stretching from the river bank of Gambella plain (550m.a.s.l) to the central and Eastern highlands of the country with an altitude as high as 2600m (Bayetta, 1986). Within this range of altitudes and ecological diversity, there exists considerable genetic diversity within the cultivated and traditionally recognized land races of arabica coffee in Ethiopia (Dessalegn, 2002).

A number of important characteristics or traits have been recorded in Ethiopian coffee, such as resistance to coffee leaf rust (Hemileia vastatrix) (Wondimu,1998), nematodes (Meloidogyneincognita) (Anzueto et al., 2001), coffee berry disease (Colletotrichum kahawae) (Bellachew et al., 2000), as well as a wide range of variations in green bean biochemical compounds (caffeine, chlorogenic acids, sucrose and trigonelline) composition (Ky et al., 2001), tree size and shape, bean size, shape and color (Wondimu, 1998) and many other characters which are useful for improvement program.

Ethiopia is also well-known for its very fine cup quality, unique aroma and flavor across coffee growing areas. Some of the famous coffee types that are acclaimed for having such unique and distinct characteristics include Sidamo, Yirgachefe, Hararge, Ghimbi and Limu (Workafes and Kassu, 2000).

Despite the existence of high genetic diversity in coffee population that provides immense opportunities for improvement program, shortage of improved varieties (pure line and hybrid varieties) is the major one (Bayetta, 2001; Mesfin, 1988; Babur, 2009). It is obvious that research work carried out so far on coffee genetics and breeding was not adequate to address these diverse agro-ecologies of the country. In any crop breeding program intended to address such problems like the ones mentioned above, heterosis and combining ability studies are some of the basic breeding tools. Nevertheless, such studies on coffee are scanty at both national and international level.

As mentioned earlier, the analysis of combining ability is the other important tool which has presently become an integral part of a breeding program. It helps to identify the best combining parent, to know the type of 
gene action involved in controlling the expression of a character and to choose appropriate breeding methods (Sprague and Tatum, 1942; Mathur and Mathur, 1983). Indeed, diallel analysis for combining ability suggested by Griffing (1956) is one of the powerful tools to provide the above information. In Arabica coffee, information in this regard is very scarce.

Therefore, the present review on coffee heterosis and combining ability study was initiated to conduct systematic investigations by concentrating on crosses between variable parental lines originated from specific country, in this case region of Ethiopia, and contribute to identify the current problem of coffee heterosis and combining ability that leads to solve coffee heterosis and combining ability problems towards improving productivity and quality in the long term.

\section{Discussion}

\subsection{Hybrid coffee variety development program in Ethiopia}

Hybridization is away in which desirable characters of two or more species, varieties or lines are combined together or transfer from one to other (Simmonds, 1986). In Ethiopia, coffee hybridization program was started in 1978, right after the release of the first batch of coffee berry disease (CBD) resistant varieties. The main objectives were to study genetic inheritance of important traits, generate basic genetic information on coffee and develop hybrid varieties with better characters over the pure lines released through selection. To this effect, different sets of crosses were made among parental lines selected for desirable characters such as yield, resistance to coffee berry disease (CBD) and coffee leaf rust (CLR), quality, vigor and others. From the various hybridization studies, a number of useful results were obtained. Among others, partial to complete dominance of the CBD susceptible alleles over the resistance alleles, involvement of a maximum of two to five recessive genes in controlling CBD, lack of cytoplasmic inheritance, presence of considerable amount of heterosis for yield and some important growth characters, importance of both additive and non-additive gene actions in controlling inheritance of CBD and the expression of yield and some yield related growth characters, and the importance of testing of different sets of crosses in different locations over several years had resulted in the release of the first three hybrid varieties that combine high yield, moderate resistance to CBD and CLR and acceptable quality in 1997 and 2002 for production at medium altitude coffee growing areas of the country.

Continuous efforts made in hybridization study to bring about improvement in coffee yield had resulted in the release of additional three new hybrid verities, in 2016 that were recommended for production at low and medium altitude coffee growing areas (JARC, 2016). Similarly, hybrid variety development effort for higher altitude areas with high CBD pressure is currently under final stage of evaluation. On the other hand, effort is under way to improve quality through selection and hybridization. In this regard, elite parental lines were identified and crossed to develop hybrid varieties with good quality for Limu, Harerghe and Wollega coffee producing regions as part of local landrace variety development program (JARC, 2016).

In general, the findings from various sets of hybridization studies have laid down remarkable foundations for present and future national breeding program in the development of hybrid coffee varieties. The results so far achieved had also clearly indicated the possibility to improve the productivity and growth performance of the crop through pure line and hybrid coffee varieties development. This approach is well applicable to developing improved varieties for different coffee growing regions of Ethiopia having diverse coffee types, agro ecologies and quality profiles.

\subsection{Heterosis in coffee}

Information on heterosis in C. arabica is relatively scanty compared to other crops since its hybridization studies had started quite recently. The perennial nature of the crop is another challenge as it requires several years to obtain meaningful results (Cilas et al., 1998). Consequently, research results on the effect of heterosis are limited. In heterosis breeding, it has been established that the more distant the parents in origin (geographical separation), ancestral relationships, gene frequencies and morphological characteristics, the greater is the potential for heterosis manifestation (Falconer, 1996).

In Ethiopia, where maximum diversity of C. arabica lines are expected to exist, heterosis over the better parent of up to $60 \%$ for yield was reported (Mesfin and Bayetta, 1983). Out of nine F1 hybrids only one hybrid exhibited negative heterosis of -8\%. The highest yielding hybrids, 7396 x F59 (Melko-CH2) and 741 x F59 (Ababuna), which have been approved for release to growers showed $20 \%$ and $18 \%$ heterosis over the better parent, respectively. The actual yield of these hybrids were 23.97 and 23.68 quintals per ha, respectively, on the basis of 2500 trees/hectare or 31.96 and 31.57 quintals of clean coffee on the basis of 3333 trees/hectare, respectively. In addition, these hybrids have shown up to $12 \%$ heterosis over the better parent for primary nodes (Mesfin, 1982).

In another $6 \times 6$ half diallel cross where 18 seedling characters (seven for shoot, six for leaf and five root characters) were considered, maximum better parent heterosis of $69 \%$ for inter node length was found (Bayeta, 1991). Bayeta (2001) also reported mid- and better- parent heterosis of up to $68 \%$ and $53 \%$ for fresh cherry yield 
and $73 \%$ and $57 \%$ for clean coffee, respectively.

On the other hand, heterosis was reported to be lacking in crosses of selected indigenous C. arabica L. varieties in Brazil after several years of studies (Carvalho et al., 1969) mainly due to lack of diverse parental lines. In conformity to this, Bayetta et al., (2007) reported that hybrids having parents of similar origin but distinct differences in growth habit has exhibited high and significant heterosis effect.

Wasu (2011) also concluded that coffee hybrids generated from distant parents both in origin and growth habit were most heterotic for coffee yield. Other group of hybrids which had distant parents in origin but similar growth habit was the second most heterotic hybrids. The lowest magnitude of Heterosis was recorded for hybrids having both parents similar in origin and growth habit. Wassu observed that an increase in heterosis was highly associated with increasing parental distance. This result clearly showed that the presence of diversity among parental lines is a prerequisite in hybrid variety development program.

Dula et al., (2018) studied heterosis and combining ability analysis for morphological characters in Western Ethiopian origin coffee and reported that proper choice of parental lines with distinct morphological variations is of paramount importance in a breeding program to obtain certain hybrids that outperforms its parent's or the character of interest. Parental lines that are morphologically similar in their morphological characters could not necessarily produce hybrid vigor.

He further noted that, the observed level of positive heterosis over the mid and better parent for characters of plant height, canopy diameter, average length of primary branch and number of primary branches may suggest that dominant and partially dominant genes were important in controlling the expression of those characters and that hybridization could be the best approach to improve the performance of these characters. In contrast, for characters height up to first primary branch, leaf length and leaf width in which the hybrids manifested negative mid and better-parent heterosis, both partial and dominance effects of genes are probably lacking and hence, selection is the best method as opposed to hybridization to improve those traits.

In Tanzania, (Ferine, 1970) reported 53\% and $11 \%$ heterosis over the mean of two standard varieties and over the better parent for yield and stem diameter, respectively. The yield of superior hybrid was $16 \mathrm{q} / \mathrm{ha}$ of clean coffee. The same author reported the presence of hybrid vigour in coffee from Costarica and Uganda. In India, Srinivasan and Vishveshwara (1978) reported yield heterosis of $86 \%$ and $100 \%$ over the better parent from crosses Agaro x 2045 and Chochie x 1934, respectively. In Tanzania and India the hybrids that showed significant heterosis had their complementary parents, VC496 and Chochie, which were of Ethiopian origin. This results clearly suggested that the presence of enormous genetic variability in Ethiopian origin coffee.

Bayetta et al., (2007) also reported that the hybrids that exhibit the highest mid- and better parent heterosis do not always exhibit the highest yield if the two parents are basically low yielders. He further noted that, economically sound heterosis is the standard heterosis i.e. heterosis over the standard check, and hence selection and ranking of hybrids based on the degree of mid and better parent heterosis per se is misleading in view of the commercial importance of the hybrids specially if the parents are low yielders. This result showed that candidate hybrids for release must be compared to the standard checks before getting released as commercial variety significant heterosis effect.

In all the coffee hybridization studies reviewed above, all hybrids that exhibited the highest heterosis percentage did not necessarily exhibit the highest yield suggesting that selection of hybrids based on the degree of heterosis perse is misleading.

\subsection{Combining ability effect in coffee}

Before embarking on any improvement program, genetic information regarding the inheritance of quantitative characters, particularly the nature and magnitude of gene action governing the inheritance of the character should be determined. For instance, results of several investigators of combining ability analyses for yield and morphological characters in coffee demonstrated that both additive and non-additive types of gene actions are important in the inheritance of these traits (Bayetta, 2001; Wassu, 2004; Ayano et al., 2014; Dula et al., 2018). However, the non-additive gene action was more important than the additive components for most traits. In Ethiopia, even though not extensive, some combining ability studies had been conducted in coffee for yield and some important morphological traits that could be used as a base for the future study.

Ayano et al., (2014) studied combining ability for yield and morphological characters in diallel crosses among five parental lines originated from south western Ethiopia. He found that the mean squares for both GCA (general combining ability) and SCA (specific combining ability) effects in across location analysis were highly significant for yield, indicating that both additive and non-additive gene actions are important for the inheritance of this economic trait. However, the high percentage contribution of SCA over GCA may indicate the predominance of non-additive gene action. Both the additive and non-additive gene actions were also found important in the control of fruit length, fruit width, fruit thickness, bean length, bean width, bean thickness and 100 -bean weight.

Ayano et al., (2015) further reported that for the fruit and bean traits studied, the relative contribution of 
GCA was predominant suggesting the greater contribution of additive gene action for these traits. But for majority of fruit and bean characters GCA with environmental interaction (GCA $x$ E) and SCA with environmental interaction (SCA x E) were significant indicating inconsistent results across locations and hence the need to depend on GCA and SCA effects of each locations.

Wassu (2011) studied combining ability for Coffee Quality in Diallel Crosses among five parents from southwestern Ethiopia (Kaffa type) and south Eastern Ethiopia (Sidamo type). He observed that, the hybrids exhibited positive and significant heterosis that ranged from 14 to $33 \%$ relative to the commercial Sidamo coffee variety for most of the parameters studied. Particularly, two hybrids, viz. 7440 x 75227 and 744 x 1681 were evaluated as having highly acceptable Sidamo coffee quality were the best specific combinations for all coffee quality parameters. He found Two Kaffa coffee parents namely, 7440 and 75227, which were good combiners and produced hybrids better than the commercial Sidamo coffee variety. He also reported that non-additive gene actions were important for acidity, body, cup quality and overall quality and additive gene action for flavor. These studies suggested that selection of parents on the basis of their quality performance and crossing among them is an important breeding approach to improve the quality of coffee in a particular area or region.

Wassu (2004), also reported genetic analysis of GCA and SCA showed that mean squares of both General combining ability (GCA) and Specific combining ability (SCA) were significant for stem girth, plant height, average number of nodes on main stem, number of secondary and tertiary branches, clean coffee yield and single berry weight. This result suggested that, both additive and non additive gene actions were important in controlling the expression of these characters. However, the primary importance of non-additive gene actions for all characters except average inter-node length was noted.

Dula et al., (2018), noted that the extent of mean squares due to SCA were higher than that of GCA and the components of variances ratios were less than unity, the non-additive gene actions were probably of primary importance in the inheritance of all the morphological traits studied. He further noted that, when non-additive gene action is predominant in the expression of a trait, selection will not be effective to improve the character in question. This findings thus may suggested that the limited efficiency of selection method to improve the characters considered and the need to consider other breeding methods such as hybridization which enables to exploit the advantage of dominant gene effects.

Bayeta (2001) also reported on the importance of additive and non-additive gene action in controlling the inheritance of yield, fruit length and morphological traits. However, he noted that additive gene action was probably predominant as indicated by larger GCA than SCA mean squares for most the character evaluated. He also observed that good general combiners have multiple advantages in that they often have high probabilities of good specific combining abilities, allow for the development of synthetic varieties, and are ideal choices as parents in a hybrid program. In addition, the hybrids with the highest SCA effects were observed evolving from any possible combination of parents having negative and positive GCA effects, the negative $\mathrm{x}$ positive crosses producing hybrids with the highest SCA effects more frequently than other combinations.

Dula et al., (2018) also observed that some crosses that involved parents with good general combiners were poor specific combinations. This result may suggest that parents with high general combining ability effect (GCA) might not always yield crosses with high specific combining ability effects (SCA) and also parents with negative general combining ability effect might not always produce crosses with low specific combining ability effects for all the agronomic traits of interest.

In conformity to this, Clias et al., (1998) reported absence of correlation between performance of lines and their GCA effect when used as parent. In this study some poorly yielding lines (Two Ethiopian lines Et3 and Et7) performed better as parent, while one high yielding variety (Java) classified as poor parent for the same trait. These two investigations may indicate that a coffee hybrid that had desirable traits could be obtained from any possible parental combination with positive or negative GCA effects. In addition, a parent that performed well as pure line may not be good general combiner when used as parent in crossing. This indicated that the average performance of parents could not be used as predictors of their general combining ability.

\subsection{Opportunities and Challenges of coffee hybridization in Ethiopia}

In $C$. arabica improvement in Ethiopia, the initial breeding objectives were to increase vigrousity, productivity and adaptability to local conditions. To achieve these objectives, breeding strategies were directed towards identification of superior plants in the population in order to develop improved pure line cultivars and crossing among the superior cultivars to develop hybrid varieties (Tadesse, 2017). Among different tools on breeder hands heterosis and combining ability study is the major breeding tools to achieve these objectives in Ethiopia. On the other hand, breeding programs in Arabica coffee are limited due mainly to narrow genetic bases in almost all coffee producing countries except Ethiopia and this has greatly hindered quick development of improved varieties which are high in yield, quality, insect pest and disease resistance and other desirable traits (Vossen, 1985). Ethiopia being the center of origin and genetic diversity of Arabica coffee is lucky in this regard but because of limited human-, physical- and financial-resources in coffee research, it was not possible to effectively 
exploit this opportunity.

Besides very little work has been done on coffee hybridization program through heterosis and combining ability analysis and therefore, it necessitates urgent action for well designed strategic morphological, molecular and biochemical characterization for future coffee hybridization work and efficient utilization of the available genetic variations.

\section{Conclusion}

Ethiopia is both the center of origin and diversification of Coffee arabica. Despite the existence of high genetic diversity in coffee population that provides immense opportunities for improvement program, shortage of improved varieties (pure line and hybrid varieties) is the major one. In any crop breeding program intended to address such problems like the ones mentioned above, heterosis and combining ability studies are some of the basic breeding tools. Nevertheless, such studies on coffee are scanty at both national and international level. However, some studies had been focused on assessment of heterosis and combining ability analysis for yield and morphological characters of coffee in Ethiopia. These studies concluded that presence of heterosis in crosses of selected indigenous C. arabica L. varieties in Ethiopia under different sets of crosses studied mainly due to presence of diverse parental lines. Hence, the first three hybrid varieties were released that combine high yield, moderate resistance to coffee berry disease and coffee leaf rust and acceptable quality in 1997 and 2002 for production at medium altitude coffee growing areas of the country. Besides, three new hybrid varieties were added in 2016 that were recommended for production at low and medium altitude coffee growing areas. Efforts are underway to develop hybrid varieties with good quality for different regions of Ethiopia, namely; Limu, Harerghe and Wollega coffee producing areas.

\section{Recommendations}

From the various sets of pure lines variety development program in Ethiopia, it had been observed that it is rarely possible to improve yield above $1800-2000 \mathrm{~kg} /$ ha through direct selection indicating the need to look heterotic hybrids to maximize yield as high as $2500-3000 \mathrm{~kg} / \mathrm{ha}$. Thus, it could be useful to further evaluate the performance of the best performing hybrids for yield and growth characters at full bearing stage to identify high yielding and vigorous hybrids for commercial use.

\section{References}

Anzueto F, Bertrand B, Sarah J.L, Eskes A.B and Decazy B, 2001. Resistance to Meloidogyne in cognita in Ethiopian Coffea arabica accessions. Euphytica 118: 1-8.

Ayano Ashenafi, Sentayehu Alamiro and Abush Tasfaye, 2014. Combining Ability for Yield and Morphological Characters in Southwestern Ethiopian Origin Coffee Hybrids. Sky Journal of Agricultural Research Vol. $3(7)$, pp. $128-136$.

Ayano Ashenafi, Sentayehu Alamiro and Abush Tasfaye, 2015. Heterosis and Combining Ability of Fruit and Bean Characters in Ethiopian Origin Coffee Hybrids. Journal of Biology, Agriculture and Healthcare Vol.5, No.11.

Babur D, 2009. Effectiveness of farmer field school in promoting coffee management practices: the case of Jima and Sidama Zones. Msc. Thesis presented to school of graduate studies of Haramaya University.

Bayetta Bellachew, 1986. Exploration and collection of coffee germplasm from Gambella plain. IAR news letter. Addis Ababa. 1 (2): 3-5.

Bayetta Bellachew, 1991. Nursery evaluation of heterosis and combining ability in reference to origin and morphology of parents in coffee (coffee arabica L.) M.sc Thesis, Alemaya University of Agriculture, Alemaya, Ethiopia.

Bayetta Bellachew, 2001. Arabica coffee breeding for yield and resistance to coffee berry disease (Colletotrichum kahawae Sp.nov.). A PhD degree thesis submitted to the University of London.

Bayetta Bellachew, Behailu, Atero., Fikadu, Tefera., Ashenafi Ayano and Tadesse Beneti, 2007. Genetic diversity and heterosis in arabica coffee. In: Girma, Adugna., Bayetta, Bellachew., Tesfaye, Shimbir., Endale, Taye. and Taye, Kufa. (eds.). Coffee Diversity and Knowledge, Four Decades of Coffee Research and Development in Ethiopia. Proceedings of National Workshop, 14-17 August 2007, Addis Ababa (Ghion Hotel) Ethiopia. pp. 328-334.

Bellachew Bayyeta, Bahilu Atero and Fikadu Tefera, 2000. Breeding for resistance to coffee berry disease.

Carvalho A and Monaco L.C, 1969. The breeding of arabica coffee. In: Fewerda, F. P. and Wit, F. (eds.), Outlines of Perennial Crop Breeding in the Tropics.

Cilas C, Bouharmont P, Boccara M, Eskes AB, Boradat PH, 1998. Prediction of genetic value for coffee production in Coffea arabica from a half diallel with lines and hybrids. Euphytica 104:49-59.

Cilas C, Bouharmont P, Boccara M, Eskes AB, Boradat PH, 1998. Prediction of genetic value for coffee production in Coffea arabica from a half diallel with lines and hybrids. Euphytica 104:49-59. 
Coste R, 1992. Coffee the Plant and the Product. MacMillan Press, London.

CSA, 2016/2017. Report on area and production of crops by Central Statistics Agency agricultural sample survey in 2017/2016, Addis Ababa, Ethiopia.

Davis A.P, Gole T.W, Bean S and Moat J, 2012. The impact of climate change on natural populations of Arabica coffee: Predicting future trends and identifying priorities. PLoS ONE, 7(11): e47981.

Dessalegn, Y., 2002. Coffee bearing unusual flowers and berries. Agri Topia 17: 12-14.

Dula Geneti, Bayetta Bellachew and Ermias Habte, 2018. Heterosis and Combining Ability Analysis for Morphological Characters in Western Ethiopian Origin Coffee (Coffea arabica L.). M.sc Thesis, Ambo University College of Agriculture and Veterinary Science, Ambo, Ethiopia.

Falconer DS, Mackay FC, 1996. Introduction to quantitative genetics. Longman, New York.

Ferine L.M, 1970. Clonal trail of Lyamungu F1 hybrids. Research Report 1967 Coffee Research Station, Lyamungu, Tanzania. pp. 22-23.

Gichuru EK, Agwanda CO, Combes MC, Mutitu EW, Ngugi ECK, Bertrand B, Lashermes P, 2008. Identification of molecular markers linked to a gene conferring resistance to coffee berry disease Colletotrichum kahawae in Coffea arabica. Plant Pathology, 57:1117-1124.

Griffing B, 1956. Concept of general combining ability and specific combining ability in relation to diallel crossing system. Australia Journal Biological Science, 9: 463-493.

JARC, 2016. Jimma Agricultural Research Center, coffee breeding progress report for the period 2016.

Ky C. L, Louarn J, Dussert S, Guyot B, Hamon S and Noirot M, 2001. Caffeine, trigonelline, chlorogenic acids and sucrose diversity in wild Coffea arabica L. and C. canephora P. accessions. Food Chemistry, 75: 223230.

Mathure P.N, and Mathur J.R, 1983. Combining ability for yield and its components in pearl millet. Indian Journal Genetics in Plant Breeding, 43:299-303. Meloidogyne incognita in Ethiopian Coffea arabica accessions. Euphytica 118: 1-8.

Mesfin Ameha and Bayetta Bellachew, (1983). Heterosis in crosses of indigenous coffee selected for yield and resistance to coffee berry disease: II. First three years. Ethiopia Journal Agricultural Science, V: 13 - 21.

Mesfin Ameha and Bayetta Bellachew, 1982. "Resistance of the F1 to coffee berry disease in six parent diallel crosses in coffee." 1984. P.107-117. In: Proc.1st Reg. workshop “coffee berry disease", 19-23 July 1982, Addis Ababa.

Mesfin Ameha, 1988. Recommendation Adoption and impact of Improved Coffee Production Technologies in the Western Region of Ethiopia. pp. 136-141. In: 20th NCIC, 28-30 Mar 1988, Addis Ababa.

Simmonds. N.W. 1986. Principles of crop improvement. Singh, B.D., 1993. Plant Breeding. Kalyani Pub. New Delhi, India. $896 \mathrm{p}$.

Sprague G.F and Tatum L.A, 1942. General versus specific combining ability in single crosses of corn. Journal of American Society Agronomy, 34: 923-932.

Srinivasan C.S, and Vishveshwara S, 1978: Heterosis and stability for yield in arabica coffee. India Journal of Genetics in Plant Breeding, 38, 13-21.

Taddesse Benti, 2017. Progress in Arabica Coffee Breeding in Ethiopia: Achievements, Challenges and Prospects.

Van der Vossen H.A.M, 1985. Coffee selection and breeding. In: Clifford, M.N. and Wilson, K.C. (eds.).Coffee: Botany, Biochemistry and Production of Beans and Beverage. Crom Helm Ltd., London. pp. n48-49.

Veddeler D, Olschewski R, Tscharntke T. \& Klein A.M, 2008. 'The contribution of nonmanaged social bees to coffee production: new economic insights based on farm-scale yield data'. Agro forestry Systems, 73: 109114.

Wassu Mohammed, 2004. Heterosis and combining ability analysis of yield and yield related traits in coffee (coffee arabica L.). M.sc Thesis, Alemaya University of agriculture, Alemaya, Ethiopia.

Wassu Mohammed, 2011. Heterosis and Combining Ability Analysis for Coffee Quality in Diallel Crosses of Diverse Coffee Parents in Origin. East African Journal of Sciences, Volume 5 (1) 12-21.

Wassu Mohammed, 2011. Magnitude of Exploitable Heterosis for Yield and Quality Traits of Coffee Hybrids as Affected by Distant Parents in Origin and Morphology in Ethiopia. East African Journal of Sciences, Volume 5 (1) 22-36.

Wondimu M, 1998. The genetic diversity of Ethiopian coffee. Kaffa Coffee 1: 25-30.

Workafes W, Kassu K, 2000. Coffee production system in Ethiopia. Pp 90-106. In: Proceedings of work-shop on control of coffee berry disease in Ethiopia.13-15th. August 1999, Addis Ababa, Ethiopia. 